\title{
A vingança do poeta
}

Marcos Siscar ${ }^{\mathrm{i}}$

\section{Cena única}

confuso entre moscas e galhos

de fenomenologia cansado

estar ou não estar: eis o poeta

com uma goiaba na mão

primeiro rústico (o poeta)

não sou eu nela não me representa não me revela

agora é que eu sou ela

eu dentro dela vou vivendo sob a pele enferrujada e amarela

segundo rústico (o verme)

sou da goiaba o bicho metódico

sua boa sintaxe sua moral sua bênção

meus buracos o guiam e protegem

ora a vida é uma goiaba bichada

basta seguir os rumos da perfuração 
(ri)

primeiro rústico (engole a goiaba)

A Sebastião Uchoa Leite

Eutomia, Recife, 26(1): 292-296, Dez. 2020 


\section{Cemitério de leucenas}

1.

Não é fácil remover todos esses galhos, folhagens, bagos secos. Todos esses restos. O fundo do quintal é de difícil acesso. É preciso chegar até ele. Criar ali um espaço de vida. Ali estão as ervas daninhas, os entulhos, excrecências não absorvidas pelo solo. Estão também restos de afetos, ideias abandonadas à exaustão. É preciso civilizá-lo. Evitar a gangrena. Que acabe tomado pela densa folhagem das leucenas. O solo é úmido e escuro. Propício à ávida disseminação.

2.

Minhas leucenas são impositivas, invasoras. Vieram de longe e se espalharam. Estão por todo o quintal. As sementes voam com o vento, entram pelas frestas, vêm trazidas pelas botas, pela distração dos pássaros. Têm 100\% de germinação. Crescem na terra e em toda parte. Sobre plantas mortas, sobre pedras porosas, sobre folhas de caderno. Em dias de ventania, fecho janelas e abro os poros. Ouço-as batendo na vidraça. Imagino que já tenham atravessado os vãos da veneziana. Sonho que germinam em meu ouvido. Que florescem em minha língua.

3.

É preciso habitar o fundo do quintal. Sempre foi preciso. Mas meu dorso agora hesita. Verga sob o peso dos galhos. A respiração é ofegante. A passagem pelo mato envolve obstáculos mais complexos, doses extras de dificuldade. O impossível se apresenta todo dia! A dor exige o abandono. Mas a procrastinação é ainda mais grave. Tão grave quanto a morte. Caminho sob a chuva, escorrego na lama, me embrenho com a bota pesada entre galhos e cipós. Lá está o cemitério de leucenas. Quantidades de verde recalque. Montes de ameaças caducas, de abandonos voluntários, de decisões adiadas, de impasses sem vida. Os ossos da árvore espinhosa que abati. Lá estão as coisas separadas. Os 
troncos pesados que desabaram no jardim. Tudo o que é grande demais para a compostagem dos dias.

4 .

Um cemitério de leucenas. No início era a leucena. A leucena cobria tudo. A leucena era inelutável, um vasto mundo de galhos intrincados. Dispostos em declive, em meio a pedras e jararacas. Foi preciso domesticar a leucena. Cortar, arrancar, triturar. Antes com força e alegria, concentração e estudo. Com um sonho de leveza. De volta ao fim outra vez me curvo, caio de joelhos, saio ferido. Cada vez mais a distância se impõe, as forças me medem. Cada vez mais me desafia em dias de chuva, a roupa toda molhada, com um gesto de raiva, lançar nesse cemitério um feixe de restos. Chove intensa e abundante a chuva de verão. O coração dispara, ofegante, com um leve escurecimento da vista. Estou vivo. Luto com leucenas. Elas me conquistaram. Eu as reconquisto. Somos um ecossistema. Ainda morro por elas. Ainda acabo morrendo em cena. 


\section{Faíscas coloridas}

É assim que queria olhar para você. Bem nos olhos. Em cima dos patins. Segurando uma vela de faíscas coloridas. Com toda a infância do mundo. Sem muitas razões. Ou quem sabe sorrindo. Acendendo de repente nossos mal-entendidos. Fazendo com que se iluminem. É exatamente assim. Vindo do escuro. Emergindo da noite de outros olhos. Vestido de penúria. Olhando para você. Você é a alegria do mundo. Você é minha catástrofe. Você é toda a alegria possível. E toda catástrofe. Ofereço-lhe este fogo mínimo. É assim que queria olhar para você agora. Serenamente. Numa cerimônia sem ritual. Chegando de patins. Me aproximo devagar. É uma oferenda. Eis meu ínfimo poder. A você ofereço tudo o que não nos fizemos. Tudo o que nos espera. É assim que queria chegar até você. Amarrado no cordame como náufrago. As mãos pousadas em sua testa. Agora sinta.

\footnotetext{
${ }^{\mathrm{i}}$ Marcos Siscar, poeta, tradutor, crítico literário, Professor do Departamento de Teoria Literária da Unicamp e pesquisador $\mathrm{PQ} / \mathrm{CNPq}$.
} 